\title{
The Asymmetry in the Structures of the Variants of the Concept the Tatar Language in the Tatar, Russian and English-Speaking Mentaleses
}

\author{
Ilvira Ildusovna Kuznetsova ${ }^{1}$ \\ ${ }^{1}$ Kazan (Volga Region) Federal University, Russian Federation \\ Correspondence: Ilvira Ildusovna Kuznetsova, Kremlyovskaya Street, 18, Kazan, 420008, Russian Federation. \\ E-mail: ilvira.kuznietsova@mail.ru
}

Received: November 18, 2014

Accepted: December 15, 2014 Online Published: March 20, 2015

doi:10.5539/ass.v11n8p26

URL: http://dx.doi.org/10.5539/ass.v11n8p26

\begin{abstract}
The author of this article analyzes the results of a series of the free associative experiments with a view to identify the specific features of the basic layers and interpretive fields of the concepts Tatar Tele/Tatarskiy Yazyk/the Tatar Language in the Tatar monolingual and bilingual, Russian and English-speaking mentaleses. The author comes to the conclusion that of the concepts have different representations in the above mentioned mentaleses. The relevance of the chosen topic is determined by the necessity to single out structural particularities of the concepts under study. The author is interested in the level of the streotypeness of the concepts and ethnical identification of the linguistic identity of the Tatar, Russian and English native-speakers. The additional relevance to the present research is given by the problem of natural and artificial bilingualism.
\end{abstract}

Keywords: concept, mentalese, cognitive linguistics, sociolinguistics, linguistic consciousness, national consciousness

\section{Introduction}

The undying interest of the scientific community to the study of the concept as a psychological and ethno-linguistic category contributes to the emergence of new works within the anthropocentrism framework. However, it should be noted that in the modern cognitive linguistics there are significant differences in understanding of the concept by different schools of thought and individual scientists (Popova \& Sternin, 2014).

According to R. Jackendoff, the concept is an equivalent to the semantic structure of the word that is identified with the conceptual structure (Jackendoff, 1983).

In his works Ch. Fillmore uses the term "frame" that is understood as cognitive structures, scholastic attainments determined by the concepts represented by words (Fillmore, 1992, pp. 46-66). According to G. Lakoff, the concept is the meaning of word that correlates with the specific cognitive contexts (Lakoff \& Gallese, 2005).

In their book "The semantic and cognitive analysis of the language" prof. Z. D. Popova and I. A. Sternin describe the concept as "a discretionary mental formation that is the basic unit of the thinking code of a person". It has "an ordered internal structure that is the result of cognitive work of the individual and society, contains comprehensive, encyclopedic information about the object or phenomenon it reflects, the interpretation of this information by social mind and the attitude to the subject or phenomenon" (Popova \& Sternin, 2006).

Thus, as a tentative definition of the concept we have taken the following "the concept is a kind of mental formation that contains the information about some object of reality, on the one hand, and the element of national specificity in its content, on the other" (Musina, 2008).

Since the linguistic landscape is the subject to constant changes in the conditions of the formation and development of the modern global civilization, the "language barrier" problem is no longer identified with the sections, mediated by political boundaries and geographic distances. The tendency of the spread of the artificial bilingualism as a form of two language acquisition outside the natural bilingual environment puts a number of multidimensional issues before linguists. The study of the natural bilingualism is of particular relevance due to the historically developed multilingual situation in the territory of the Republic of Tatarstan. In this region there are two official languages: Tatar and Russian. Thus, the study of their role in the modern culture is of particular 
importance not only for linguistics but for sociological research as well.

The Tatars are the second largest ethnic group and the most numerous people of Muslim culture in the Russian Federation. The Tatar ethnic group has a long and rich history that is closely linked with the history of all the peoples of the Volga-Ural region and the whole of Russia. At present the Tatars make up over half of the population of Tatarstan that is their national republic.

Modern Tatar Language relating to the Kypchak-Bulgar subgroup of the Turkic language family is divided into four dialects. The present study investigates the implementation of the concept TATAR TELE in the central (Kazan Tatar) dialect.

Modern Tatar ethnic group originated in parallel with the Russian one. The Tatars are the Turkic-speaking part of the indigenous population of Russia. In virtue of their greater territorial proximity to the East the Tatars adopted not Orthodoxy but Islam. 99\% of believers among the Tatars are the Sunni Muslims of Moderate Hanafi version.

\section{Method}

\subsection{Methodologies}

Methodologically the study is based on the following fundamental principles of the modern linguistics. The concept as a global thought-unit having a field structure is a quantum-structured knowledge. It has a core and an extensive interpretative part. The latter is a set of poorly structured predications that reflect the interpretation of individual conceptual features and their combinations in the form of statements, attitudes of consciousness that appear in the culture from the content of the concept and are implemented in the precedent texts (Popova \& Sternin, 2001). The framework of categories and concepts of the research includes the categories of symmetry/asymmetry. Their extreme generality allows to use them not only on the paradigmatic axis (Zvegintsev, 1965), but in the syntagmatic and semiotic terms as well (Gak, 1977). Asymmetry is distinguished into static, homologous, functional (Bayramova, 2001).

In the present paper a complex method of research is used. It combines the descriptive, structural, interpretive, psycholinguistic methods and statistical methods as well. The reliability of the obtained results is determined by the sequence of their statistical processing, as well as by the use of the spectrum of methods and techniques in the interpretation of the data.

The data for study includes 1528 associative responses elicited during the set of free associative experiments, and 725 precedent texts (aphorisms, poems, lyrics, colorful expressions, etc.).

The main experimental methods and procedures of ethnopsychological research that are used nowadays are: (1) borrowed from sociology interviewing as a means of description of the model of ethnic situations; (2) inter- and introspection; (3) the method of content analysis that is the most effective in the study of ethnic relations (Privalova, 2005).

M. K. Gorshkov and F. E. Sheregi point the effectiveness of the sampling method when it is used in a single-stage and multi-stage variants. (Gorshkov \& Sheregi, 2003).

In our study we have applied the multi-stage variant of the area sampling method. It is based on the geographical, ethnic and social features. The survey of the Tatar respondents was conducted in the Volga and Zakamskij regions of the Republic of Tatarstan (Kazan, Nizhnekamsk, Yelabuga, Naberezhnye Chelny), of the Russian informants in Chelyabinsk and Tatarstan, of the English-speaking respondents in the United States of America (New York, Washington, Chicago).

\subsection{Psycholinguistic Method}

It seems that one of the most productive psycholinguistic methods used in the formation of ethnic portraits is an associative experiment. The founder of this method is considered to be a psychiatrist and psychoanalyst Carl Jung. The associative experiment has recently become the most common research procedure in linguistics and psychology, on the grounds that the linguistic knowledge enables understanding of consciousness in general and linguistic consciousness in particular.

The realization of the free associative experiment and the subsequent analysis of the verbalized reactions made it possible to implement a patterning of the basic layer and interpretive field of the variants of the concepts under study. Thus, the concept has received field description in terms of the core and periphery. It has been revealed that the basic image almost completely fills the content of the concepts Tatar Tele and Tatarskiy Yazyk in the Tatar and Russian mentaleses. There is only the basic level of the concept the Tatar Language in the English-speaking mentalese. 
In accordance with the forms of the reality reflection the set of associations named by respondents when the stimulus word presented has been devided into following groups: senses, perception, image and notion.

As we understand senses present subjective reflection of the properties of the objective world objects. This reflection occurs when the objects directly affect sensory receptors. The following senses are distinguished: visual, gustum, auditory, tactile, etc. (Oschuschenie, 2012).

We take the view that perception is the process when a person receives and processes various information reaching the brain through sense organs. Senses that reflect some individual properties of objects are different from perception by the fact that the latter presents the whole object, in the totality of its invariant properties. There can be distinguished the following types of perception: visual, auditory, tactile, gustum and olfactory (Vosprijatie, 2012).

Images are some kind of inner experience, or picture that is open to "mind's eye". They are also referred to as the experience gained in other areas of perception, such as hearing, taste and kinaesthesia (Korsini \& Auerbach, 2006).

We understand notion as some form of knowledge that displays the individual and the particular, but at the same time universal. Notion also acts both as a form of reflection of a tangible object and as a means of its mental reproduction, composition, i.e. as a special mental action. Notion furthers the implementation of substantial generalization, the transition from essence to the phenomenon (Mescheryakov \& Zinchenko, 2004).

Mathematical methods in association studies are widely used both in the foreign and Russian works in cognitive linguistics (Shannon \& Weaver, 1964), (Goroshko, 2001).

The assessment of the association norms, stereotyped reactions, stability of association norms with the calculation of probability of the response at a given frequency, deviation of a random value, entropy (measure of uncertainty), the structure of meaning, etc. has been realized by means of probability methods (Solokhina, 2004).

The mentalese as "an ordered set of concepts of the nation, the information based of thinking" is a kind of reflection of the age, gender, professional, ethnic, and cultural characteristics of the people (Popova \& Sternin, 2014).

Foreign linguists describe the mentalese as "the universal language of thought" (Gerbig \& Mason, 2008).

\section{Results}

\subsection{The Basic Layers of the Concepts under Study}

The author has made an attempt to implement the linguistic-cultural and linguo-cognitive analysis of the fragments of the Tatar, Russian and English cultures and cognitive features of these ethnic groups.

Let us consider the structure specificity of the basic layer of the variants of the concept the Tatar Language in the mentaleses under study. 735 informants from Russia and the United States at the age of 15-60 years old have taken part in the free associative experiment (referred to below as FAE). The experiment has been conducted among the Tatar, Russian and English native-speakers.

In order to differentiate the respondents we have divided the Tatar native-speakers into following groups: the monolingual Tatars (the Tatars speaking predominantly the Tatar Language) and the bilingual Tatars (the Tatars speaking both the Tatar and Russian languages). This study examines the implementation of the concept Tatar Tele in the central (Kazan Tatar) dialect.

Table 1. The core of the variants of the concept the Tatar Language in the mentaleses under study

\begin{tabular}{|c|c|}
\hline Mentalese & Most frequent responses \\
\hline Tatar & tugan tel, mother-tongue (52\%) \\
\hline monolingual & ana tele, mother's tongue $(20 \%)$ \\
\hline Tatar bilingual & $\begin{array}{l}\text { rodnaya derevnya, native village (38\%), uchitel tatarskogo yazyka, a teacher of Tatar (15\%), } \\
\text { Tatarstan }(11 \%)\end{array}$ \\
\hline Russian & Kazan (22\%), Tatarstan (16\%), Gabdulla Tukai, Tatar poet (11\%) \\
\hline English-Speaking & Tartar sauce (17\%), Turkic language (10\%), Arabic language (7\%) \\
\hline
\end{tabular}

Depending on the dominant characteristics there have been elicited the following types of the concepts: (1) notional (the concept Tatar Tele in the Tatar monolingual mentalese and the concept the Tatar Language in the 
English-speaking mentalese); (2) image (the concept Tatarskiy Yazyk in the Tatar monolingual and Russian mentaleses).

In order to estimate the validity of the results obtained during the FAE the author has used the entropy method. It provides an opportunity to evaluate the stereotypeness of the associative set and identify to what extent the stimulus word is capable of eliciting different (unique) and stereotyped responses.

Table 2 shows the level of the relative entropy. Its value ranges from 0 to 1 . The lower the level of the relative entropy, the more stereotyped the concept is considered to be. In turn, this level indicates the stereotypeness of the phenomena under study.

Table 2. Entropy in the Tatar, Russian and English-speaking mentaleses

\begin{tabular}{ll}
\hline Mentalese & Level of the relative entropy \\
\hline Tatar monolingual & 0,22 \\
Tatar bilingual & 0,45 \\
Russian & 0,45 \\
English-speaking & 1
\end{tabular}

It has been found out that the concept TATAR TELE in the Tatar monolingual mentalese is more stereotyped than the concept TATARSKIY YAZYK in the Tatar bilingual one. Interestingly, the level of the relative entropy of the concepts under study is equal both in the Tatar bilingual and Russian mentaleses. It is assumed that this fact is caused by a significant degree of influence of the Russian language on the minds and world perception of the bilingual Tatars. The stereotypeness of the concept the TATAR LANGUAGE is on the low level. It has been proved by the high level of the relative entropy.

\subsection{The Interpretive Fields of the Concepts under Study}

The interpretive fields (referred to below as IF) of the variants of the concept the TATAR LANGUAGE in the mentaleses under study have been modeled on the basis of the verbal reactions of the respodents and the precedent texts in Tatar, Russian and English as well. In modern linguistics precedent texts are considered as culturally marked lexical units. They present the result of the conceptualization and perception of the world by one or another linguoculture. (Bannikova, 2004).

The IFs of the concepts under study have been modeled on the basis of precedent texts and the answers of the respondents, afterwards the logemes have been formulated.

Logical phrase (logeme) is the thought that is a whole and dismembered reflection of reality, correlating with it its content, having structural independence and relative completeness and by virtue of these properties serving as a unity of the thinking process (Chicherina \& Klepikova, 1999).

Table 3. IFs of the variants of the concept the Tatar Language in the mentaleses under study

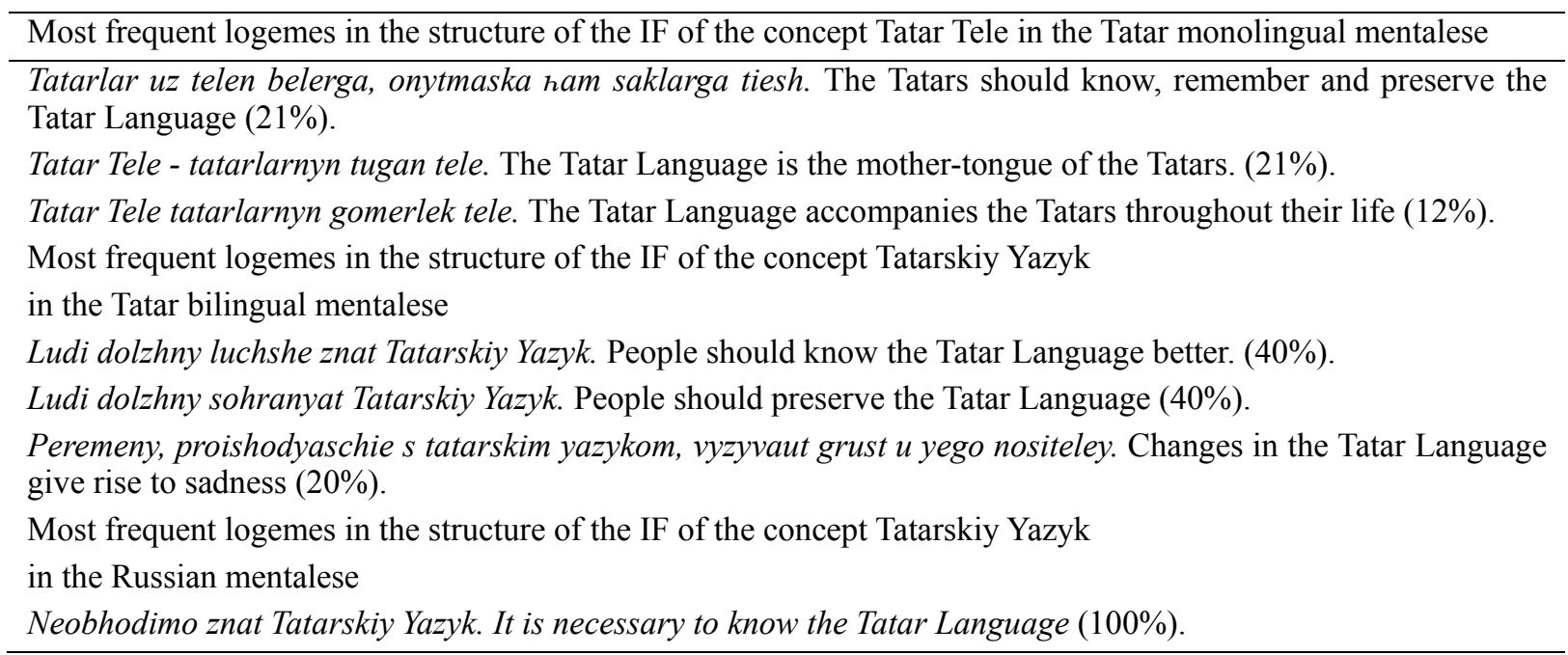


The content of the interpretive field of the concept Tatar Tele can be represented as follows: tatarlar ochen kirakle, bai, dus, monly, achyk, zirak, izge, gomerlek tugan ham aralash tele amma kup avyrlyklar kicherganga da karamastan ul keshelarga bakhet kitera, shuna kura tatarlar ana rakhmatle bulyrga, onytmaska, dores soylasherga ham telnen darazhasen yugartyrga tiesh tugel (the native language of the Tatars, being a means of communication, accompanying them throughout their lives, rich and user-friendly, melodic, wise, necessary, open, the holy language, endured many difficulties in the way of its development, however, bringing happiness to the Tatars, so they should be grateful to it, remember and love it, speak it correctly and raise its status as well).

Thus, it has been found out that the bilingual Tatars consider the Tatar Language as a language that Tatars should know and maintain. They are concerned about the changes taking place in the language.

The interpretive field of the concept Tatarskiy Yazyk in the Russian mentalese is of low-capacity and contains one logeme confirming that the Russian informants are aware of the importance of knowledge of the Tatar Language.

The symmetry of the IFs of the concepts Tatar Tele/Tatarskiy Yazyk in the Tatar mentalese is determined by the common idea "how necessary it is to know the language". The scope and content of the elicited logemes determines the asymmetry of the IFs of the concepts under study. The IF of the concept TATAR TELE in the Tatar monolingual mentalese includes 23 logemes and is realized in 144 texts; the IF of the concept TATARSKIY YAZYK in the Tatar bilingual mentalese includes 3 logemes and is realized in 5 texts; the IF of the concept TATARSKIY YAZYK in the Russian mentalese includes 14 and is realized in 84 texts. The IF of the concept the TATAR LANGUAGE in the English-speaking mentalese is not modeled.

\section{Discussion}

The composition of the cognitive features constituting the interpretative field of the concept TATAR TELE in the Tatar monolingual mentalese has revealed the fact that the Tatars are aware of the need of good knowledge, study and preservation of their native language.

The presence of the core of the concept Tatarskiy Yazyk in the Tatar bilingual mentalese proves the formedness of norms and rules of the linguocultural society which are used by each of its member.

The fact that the bilingual Tatars recognize the Tatar Language as their mother-tongue, realize the necessity to study it and enhance its status, gives evidence that the bilingual microsocium possesses the totality of the qualities that define the linguistic identity as an ethnically identified one.

The entropy method has completely confirmed the results of the conducted free associative experiment showing the stereotypeness of the concepts under study in the monolingual and bilingual Tatar mentaleses.

The concept the Tatar Language is not formed in the minds of the English native-speakers.

Having compared the results obtained in the FAE implemented in the Tatar monolingual, Tatar bilingual, Russian and English-speaking mentaleses, we summarize: (1) the asymmetry of the Tatar monolingual and Russian variants of the concept the Tatar Language is as follows: a) the concept under study in the Tatar monolingual mentalese is notional in nature, while in the Russian mentalese it is of image character; b) the concept Tatarskiy Yazyk triggers more positive emotions among bilingual Tatars, while the Russian informants represent it with neutrally colored reaction; (2) the symmetry of the Tatar variant (the Tatars speaking predominantly Russian) and the Russian variant of the concept Tatarskiy Yazyk is determined by the fact that the concept Tatarskiy Yazyk both in the Tatar bilingual and Russian mentaleses has image character; (3) the English-speaking informants associate the Tatar Language with the sauce that resembles the word "tatar" on the one hand, and with the Turkic and Arabic languages on the other.

\section{Acknowledgments}

The perspective of the research is understood in the following: (1) the compelling of the conceptual dictionary of the precedent texts in three languages under study; (2) the finding of specific features of the concept TUGAN TEL (mother-tongue) in the Tatar monolingual mentalese (the Tatars predominantly speaking Russian).

\section{References}

Bannikova, S. V. (2004). Precedent phenomena as the markers of ethnic culture. Internet-Zeitschrift für Kulturwissenschaften, 15. Retrieved from http://www.inst.at/trans/15Nr/04_09/bannikova15.htm

Bayramova, L. K. (2001). Tatarstan: yazykovaya simmetriya i asimmetriya. Kazan: Izdatelstvo Kazanskogo universiteta. 
Chicherina, N. V., \& Klepikova, T. A. (Eds.). (1999). Aspekty lingvisticheskikh i metodicheskikh issledovaniy. Arkhangelsk: Izdatelstvo PSU.

Fillmore, Ch. J. (1992). Toward a frame-based lexicon: The semantics of RISK and its neighbours (pp. 46-66). Hillsdab: Lawrence Erlbaum Associates.

Gak, V. G. (1977). Sopostavitelnaya leksikologiya: Na materiale frantsuzkogo i russkogo yazykov. Moscow: Mezhdunarodnye otnosheniya.

Gerbig, A., \& Mason, O. (2008). Language, People, Numbers: Corpus Linguistics and Society. Retrieved from http://www.books.google.ru/books?id=EcLYhIcYX3AC\&printsec=frontcover\&hl=ru\&source=gbs_ge_sum mary_r\&cad $=0 \# \mathrm{v}=$ onepage $\& \mathrm{q} \& \mathrm{f}=$ false

Goroshko, Ye. I. (2001). Integrativnaya model svobodnogo assotsiativnogo eksperimenta. Kharkiv; Moscow: RA-Caravella.

Gorshkov, M., \& Sheregi, F. (2003). Prikladnaya sotsiologia: Uchebnoe posobie dlya vuzov. Moscow: Tsentr socialnogo prognozirovaniya.

Jackendoff, R. (1983). Semantics and cognition. Cambridge: MIT Press.

Korsini, R., \& Auerbach, A. (2006). Psikhologicheskaya entsiklopedia. Retrieved from http://vocabulary.ru/ dictionary/3/word/predstavlenija

Lakoff, G., \& Gallese, V. (2005). The brain's concepts: The role of the sensory-motor system in conceptual knowledge. Cognitive Neuropsycology, 22(3/4). Retrieved from http://www.ppls.ed.ac.uk/ppig/documents/ brainconcepts_000.pdf

Mescheryakov, B., \& Zinchenko, V. (2004). Bolshoi psikhologicheskij slovar. Retrieved from http://vocabulary.ru/dictionary/30/word/ponjatie

Musina, I. I. (2008). Mezhyazykovye osobennosti realizatsii variantov kontseptov Tatarskiy Yazyk, Russkiy Yazyk, Angliyskiy Yazyk (Master's thesis, Tatar State University of Humanities and Education, Kazan, Tatarstan). Retrieved from http:// http://dlib.rsl.ru/01003167090

Oschuschenie. (2012, February 20). In Kratkij slovar psikhologicheskikh terminov. Retrieved February 21, 2012 , from http://vocabulary.ru/dictionary/16/word/oschuschenie

Popova, Z. D., \& Sternin, I. A. (2001). Ocherki po kognitivnoj ligvistike. Voronezh: Istoki.

Popova, Z. D., \& Sternin, I. A. (2006). Semantico-cognitivny analiz yazyka (p. 24). Voronezh: Istoki.

Popova, Z. D., \& Sternin, I. A. (2014). Cognitivnaya lingvistika. Retrieved from http://zinki.ru/book/kog nitivnaya-lingvistika/

Privalova, I. V. (2005). Interkultura i verbalnyj znak (lingvokognitivnye osnovy mezhkulturnoj kommunikatsii). Moscow: Gnozis.

Shannon, E. C., \& Weaver, W. (1964). The mathematical theory of communication (pp. 20-21). The University of Illinois Press.

Solokhina, A. S. (2004). Kontsept svoboda v angliyskoy i russkoy lingvokulturah (Master's thesis). Volgograd, Russia. Retrieved from http://www.lib.ua-ru.net/diss/cont/206090.html

Vosprijatie. (2012, February 20). In Kratkij slovar psihologicheskikh terminov. Retrieved February 21, 2012 , from http://vocabulary.ru/dictionary/16/word/vosprijatie

Zvegintsev, V. A. (Ed.). (1965). Istoriya yazykoznaniya XIX-XX vekov v ocherkakh i izvlecheniyakh (p. 2). Moscow: Prosveschenie.

\section{Copyrights}

Copyright for this article is retained by the author(s), with first publication rights granted to the journal.

This is an open-access article distributed under the terms and conditions of the Creative Commons Attribution license (http://creativecommons.org/licenses/by/3.0/). 